\title{
Okul Yöneticilerinin Öğretmenlerin Olumsuz Davranışlarına Yönelik Görüşleri
}

\author{
DOI: 10.26466/opus.593581 \\ * \\ $\underline{\text { Sevda Katıtaş * }}$ \\ E-Posta: sasevda@gmail.com \\ ORCID: $0000-0003-3512-6677$
}

Öz

Gelecek nesillerin yetiştirilmesinde önemli bir yere sahip olan öğretmenlerin farkında olarak ya da olmayarak yaptıkları bazı davranışlar öğrenciler üzerinde bir takım olumsuz etkiler bırakabilmektedir. Bu olumsuz etkiler öğretmenin mesleki anlamda yeterli donanıma sahip olmamasından, öğrencilerle etkili iletişim kuramamasından ya da sını yönetimini etkili bir şekilde sağlayamamasından kaynaklanabilmektedir. Alan yazın incelendiğinde olumlu öğretmen davranışlarına yönelik çok sayıda çalışmanın yapıldığı ancak olumsuz öğretmen davranışlarına yönelik yeterli sayıda çalışmanın bulunmadığı dikkat çekmektedir. Bu bağlamda, bu çalışmada okul yöneticilerinin görüşlerine göre ortaokul kurumlarında görev yapan öğretmenlerin olumsuz davranışlarının belirlenmesi amaçlanmıştır. Araştırmanın çalışma grubunu, 2017-2018 öğretim yılında Konya ilinde bulunan kamu ortaokullarında görev yapan dokuz okul yöneticisi oluşturmaktadır. Çalışma grubunun belirlenmesinde kartopu örnekleme ve maksimum çeşitlilik yöntemleri kullanılmıştır. Veriler, araştırmacı tarafından geliştirilen yarı yapılandırılmış görüşme formu ile toplanmıştır. Verilerin analizinde içerik analizi tekniği kullanılmış ve çalışmadan elde edilen bulgular ilgili alan yazın çerçevesinde tartışılmıştır. Çalışmadan elde edilen sonuçlara göre, eğitim-öğretim süreçleri kapsamında öğrenci öğrenmelerini güçleştiren, sımıf yönetimi kapsamında öğrencilerin derse karşı motivasyonların, tutumların ve katılımların olumsuz yönde etkileyen, rehberlik kapsamında öğrencilerin olumsuz duygular yaşamalarına neden olan ve son olarak başarının değerlendirilmesi kapsamında öğrencilerin başarıların tam olarak yansıtmaların engelleyen davranışlar yöneticiler tarafından olumsuz öğretmen davranışları olarak ifade edilmiştir.

Anahtar Kelimeler: Okul yöneticileri, olumsuz öğretmen davranışları, sınıf yönetimi 


\title{
School Principals' Views on Teachers' Negative Behavior
}

\begin{abstract}
Some of the behaviors of the teachers who play an important role in the training of future generations, whether they are aware or not, may have some negative effects on the students. These negative effects may be due to the fact that the teacher is not professionally equipped, cannot communicate effectively with the students or does not provide classroom management effectively. When the literature is examined, it is noteworthy that there are many studies on positive teacher behaviors but there are not enough studies on negative teacher behaviors. In this context, in this study, it was aimed to determine the negative behaviors of teachers working in secondary schools according to the opinions of school principals. The study group of the research consists of nine school principals working in public secondary schools in Konya in 2017-2018 academic year. Snowball sampling and maximum diversity methods were used to determine the study group. Data were collected with a semi-structured interview form which was developed by the researcher. Content analysis technique was used in the analysis of the data and the findings obtained from the study were discussed within the framework of the relevant literature. According to the results obtained from the study, behaviors that make student learning difficult in the context of education-teaching processes, negatively affect students' motivation, attitudes and participation in classroom management, cause students to experience negative emotions within the scope of guidance and finally prevent students from fully reflecting their achievements in the context of assessment of achievement are expressed as negative teacher behaviors by the principals.
\end{abstract}

Keywords: School principals, negative teacher behaviors, classroom management 


\section{Giriş}

Bilim ve teknolojide yaşanan gelişmeler birey ve toplumun hayatını etkilediği gibi eğitim kurumlarını da etkilemektedir. Bu açıdan bakıldığında, eğitim sisteminin en önemli ögesi olan öğretmenler toplumun gelişmesinde son derece önemli bir role sahiptir. Diğer bir ifadeyle, bir eğitim sisteminin başarısını, o sistemde görev alan öğretmenlerin niteliklerinin belirlediğini söylemek mümkündür. Çağdaş eğitim anlayışında öğretmenler alternatif öğretim stratejilerini kullanarak veya etkili öğrenme ortamları hazırlayarak öğrencilerin hem akademik yönden hem de sosyal ve kişisel yönden gelişmelerine katkı sağlamaktadır. Zira öğretmenlerin mesleklerini en iyi şekilde yapabilecek nitelik ve yeterliliklere sahip olmaları ve çağın ihtiyaçlarına cevap verebilmeleri bir ülkenin kalkınması açısından çok önemlidir.

Okulda eğitimden beklenen hedeflerin gerçekleştirilmesinde ve eğitimde verimliliğin sağlanmasında öğretmen önemli bir rol üstlenmektedir. Öğretmenlerin eğitim verme dışında öğrencilere rehberlik etme, rol model olma gibi görevleri de bulunmaktadır (Bursalığlu, 2011). Öğretmenler bu görevlerini yerine getirirken öğrencilerin bu yönlerini tanıyacak becerilere de sahip olmalıdır. Öğretmenlerin bu görevlerindeki başarı durumları, öğrencilere kazandırabildikleri ve kendilerine sunulan mevzuatı yerine getirebilmeleri ile doğru orantılıdır (Özdemir ve Sönmez, 2000). Bu bağlamda, öğretmenler mesleklerinde etkili olabilmek için bazı niteliklere sahip olmalıdır. Bu nitelikler eğitim sisteminin amaçlarına, okulun bulunduğu çevreye, veli beklentilerine, okulun misyonuna, yönetici ve öğretmenlerin vizyonuna göre değişebilmektedir (Çelikten, Şanal ve Yeni, 2005).

Danielson (2007) etkili öğretmenin niteliklerini "planlama ve hazırlık", "sınıf ortamı", "öğretim" ve "profesyonel sorumluluklar" olmak üzere dört başlık altında toplamaktadır. Buna göre, planlama ve hazırlık sürecinde öğretmenin içerik bilgisine sahip olması, öğrencileri tanıması, öğretimsel amaçları seçmesi, kaynakları tanıması, tutarlı öğretim yapması ve öğrenci öğrenmelerini değerlendirmesi önemlidir. Sınıf etkinliklerini ve öğrenci davranışlarını yönetme, öğrenme kültürü oluşturma ve fiziki çevreyi düzenleme gibi unsurlar sınıf ortamı ile ilgili faaliyetler arasında yer 
almaktadır. Öğretmenin açık ilişkiler kurması, soru sorma ve tartışma tekniklerini kullanması, öğrencileri öğretimin içine katması ve onlara geribildirim vermesi, esnek ve açıklayıcı olması gibi nitelikler ise öğretim boyutu altında değerlendirilmektedir. Öğretimle ilgili düşünme, ailelerle iletişim kurma, okula ve okul yönetimine katkıda bulunma ile profesyonelliği geliştirme gibi nitelikler de öğretmenin profesyonel sorumlulukları arasında yer almaktadir.

Öğretmen yeterliliğinin öğrenci başarısına yönelik önemli bir etkiye sahip olduğunu belirten Ashton ve Webb (1986), konuyla ilgili olarak öğretmenlerin öğrencilere karşı davranış ve yaklaşımlarının öğrenci başarılarını olumlu ya da olumsuz yönde etkilediğini vurgulamaktadır. Benzer şekilde Page (2013) ile Kyriakides ve Creemers (2011) da öğretmen davranışlarının öğrencilerin kişilik oluşumunda ve eğitimlerinde etkili olduğuna işaret etmektedirler. Bu kapsamda en yalın haliyle yeterlilik, bireyin bir davranışı yerine getirebilmesi için gerekli bilgi ve beceriyi kazanmasıdır (Celep, 2004). Bu tanımdan yola çıkarak, bir öğretmenin yeterliliğinin mesleğini yerine getirebilmesi için gerekli bilgi ve beceriyi kazanmasına bağlı olduğu söylenebilir. Öğretmenler bireysel ve mesleki düzeyde ne kadar yeterli olurlarsa; öğrencilere de o düzeyde faydalı olabilmektedirler. Bu bağlamda, çağdaş bir öğretmenin sahip olması gereken nitelikleri Demirel (1999), "kişisel nitelikler" ve "mesleki nitelikler" olmak üzere iki boyutta ele almaktadır. Yazar kişisel nitelikler boyutunda öğretmenlerin güdüleyicilik, başarıya odaklanma ve profesyonellik özellikleri üzerinde durmaktadır. Bunlardan güdüleyicilik özelliği, öğretmenin coşkulu, içten ve güvenilir olması gibi kişisel yönlerine işaret etmektedir. Başarıya odaklanma özelliği, öğretmenlerin kendileri ve öğrencileri için yüksek başarı beklentisi içerisinde olmalarıyla ilişkilidir. Profesyonellik özelliğinde ise öğretmenin işine hâkim, esnek ve bilgili olması vurgulanmaktadır. Diğer taraftan, mesleki nitelikler boyutunda ise öğretim etkinliklerinin planlanması, sınıf yönetimi, öğretim yöntem ve tekniklerinden faydalanma, etkili iletişim kurma, zamanı etkin kullanma, öğrenme sonuçlarını izleme ve rehberlik gibi teknik yeterlikler ön plana çıkmaktadır.

Çelikten ve diğerleri (2005) de ideal veya etkili bir öğretmende bulunması gereken nitelikleri Demirel'in (1999) sınıflamasıyla benzer şekilde ele 
alarak "kişisel özellikler" ve "mesleki özellikler" alt boyutlarıyla gruplandırmışlardır. Etkili öğretmenlerin sahip olması gereken özellikler bu alt boyutlar çerçevesinde aşağıda açıklanmaktadır:

Kişisel Özellikler. Çelikten ve diğerleri (2005), etkili öğretmenin özellikleri hakkında herkesin ortak bir noktada buluştuğu belirli standartların varlığından söz edilemeyeceğini dile getirmekle birlikte tüm eğitimcilerin üzerinde uzlaştıkları en önemli kişisel özellikleri şu şekilde sıralamaktadırlar: a) Öğrenciye karşı açık fikirli olma ve objektif davranma, b) Öğrencinin beklenti ve gereksinimlerini önemseme, c) Eğitsel sorunlara bilimsel yöntemlerle çözüm arama d) Öğrenciler arasındaki bireysel farklılıklarını göz önünde bulundurma, e) Yenilik ve gelişmeleri takip ederek kendini devamlı yenileyebilme f) Toplumda yaşanan değişme ve gelişmeleri anlayarak yorumlayabilme, g) Eğitim teknolojilerindeki gelişmeleri yakından izleme h) Araştırmacı bir yapıya sahip olma, 1) Öğrencilerle ilgili yüksek başarı beklentisine sahip olma.

Mesleki Özellikler. Etkili bir öğretmen olumlu kişisel özelliklerin yanı sıra mesleki özelliklere de sahip olmalıdır. Öğretmenin mesleki özelliklerini genel kültür, alan bilgisi ve öğretmenlik meslek bilgisi olmak üzere üç başlık altında incelemek mümkündür:

Genel Kültür. Öğretmenin en önemli görevi öğrencinin sosyalleşmesine ve toplumsal kültürün öğrenciye aktarılmasına yardımcı olmaktır. Öğretmenin bu görevini başarıyla yerine getirebilmesi için bulunduğu toplumun kültürel özelliklerini iyi bilmesi gerekmektedir. Öğretmen ayrıca öğrenci ve velilerle çatışma yaşamamak için velilerin yaşam tarzı, değer ve normları gibi konularda da bilgi sahibi olmalıdır (Erden, 1999).

Alan Bilgisi. Alan bilgisi bakımından öğretmenin yeterli olması oldukça önemlidir. Öğretmenin öğrenci sorularına cevap verememesi,anlattığı konuya hâkim olmaması, konuyu örneklendirirken zorlanması gibi durumlarda öğrenci öğrenmeleri ve dolayısıyla öğrenci başarıları olumsuz yönde etkilenmektedir (Gençtanırım, Torunoğlu ve Köroğlu, 2014).

$\ddot{O} \breve{g r e t m e n l i k ~ M e s l e k ~ B i l g i s i . ~ O ̈ g ̆ r e t m e n i n ~ b e l i r l i ~ b i r ~ a l a n a ~ v e y a ~ k o n u y a ~}$ hakim olması öğretimin başarılı bir şekilde gerçekleşmesinde yeterli değildir. Öğretmen, bildiğini öğretirken nasıl bir yol izlemesi gerektiğini diğer bir ifadeyle öğrencilere nasıl aktaracağını da bilmelidir. Bir öğretmen alanında uzmanlık bilgisine sahip olmanın yanı sıra öğretmenlik mesleğine yönelik bir takım bilgi ve becerilere de sahip olmalıdır (Erden, 1999). 
Öğretmenlerin sahip olması gereken mesleki nitelikler öğretim sürecini planlama, derslerde yardımcı materyal ve teknolojiden faydalanarak çeşitliliği sağlama, öğretim süresini etkili kullanma, öğrencilerin etkin katılımını sağlayacak şekilde öğrenme ortamını düzenleme, öğrenci gelişimini izleme şeklinde özetlenebilir (Çelikten ve diğerleri, 2005).

Yukarıda bahsi geçen ve etkili bir öğretmende bulunması gereken kişisel ve mesleki özellikler şüphesiz öğrencilerin davranışlarını olumlu yönde etkilemede ve onların bilişsel ve sosyal açıdan gelişmelerinde önemli bir yere sahiptir. Ancak bununla birlikte öğretmenlerin eğitim-öğretim sürecinde bilinçli ya da bilinçsiz olarak sergiledikleri ve dolayısıyla öğrenci gelişimlerini olumsuz yönde etkiledikleri bazı olumsuz davranışları olabilmektedir. Olumsuz davranışlar genel olarak duruma veya ortama uygun olmayan ancak bilinçli yapılan davranışları içermektedir (Pala, 2005). Başar (2003) eğitimde eğitsel süreçlerin ilerlemesine engel olan her türlü davranışı, olumsuz davranış şeklinde nitelendirilmektedir. Balay ve Sağlam (2008) okuldaki ve sınıftaki eğitsel çabaların gerçekleşmesini önleyen davranışların tamamını olumsuz davranışlar grubunda sınıflandırmaktadır. Lewis ve Riley (2009) ise olumsuz öğretmen davranışlarını yasal ve yasal olmayan davranışlar şeklinde ikiye ayırmaktadır. Yazarlara göre yasal olmayan olumsuz davranışlar fiziksel veya cinsel kötü muamele, istismar ve hırsızlık gibi yasaların ihlaliyle ilgili öğretmen davranışlarını içermektedir. Diğer taraftan sınıflarda sıkça karşılaşılan ve yasal olarak kabul edilen olumsuz öğretmen davranışları ise sürekli kızma, eleştirme ve alay etme gibi davranışları kapsamaktadır. Kısaca, öğretmeöğrenme etkinliklerini önleyen veya sınıfın genel atmosferini bozarak öğrencileri olumsuz yönde etkileyen bütün davranışları olumsuz davranış olarak değerlendirebiliriz. Semlak ve Pearson'a (2008) göre, bu tür davranışlar öğretmen ve öğrenciler arasındaki iletişimi azalttığı gibi öğrenmeyi de olumsuz yönde etkilemektedir. Öyle ki öğrencilerin motivasyonları düşmekte, derse katılımları olumsuz yönde etkilenmekte ve dolayısıyla bilişsel ve duyuşsal öğrenme azalmaktadır.

Sonuç olarak, olumsuz davranış denildiğinde ilk olarak öğrencilerin olumsuz davranışları akla gelse de öğretmenlerin de bazı olumsuz davranışları olabilmekte ve bu olumsuz davranışlar öğrenci davranışları ve öğrenmeleri üzerinde bir takım olumsuz sonuçlara yol açabilmektedir. Literatürde olumsuz öğretmen davranışlarına yönelik yapılan çalışmalar 
dikkate alındığında, Roberson ve Doebler'ın (2001) bir çalışmasında öğretmenlerin derste isteksiz olmaları, öğrencilerin bireysel ihtiyaçlarını göz önünde bulundurmamaları, farklı materyal ve öğretim yöntemlerini kullanmamaları öğrencilerin bakış açısıyla olumsuz öğretmen davranışları olarak değerlendirilmiştir. Weishew ve Peng' in (1993) çalışmasında öğretmenin sınıfta tekdüze konuşması, öğrencileri motive edememesi, çelişkili yönergeler vermesi, öğrenci başarısını değerlendirmede yanlı davranması, öğrencilere yönelik mantıklı olmayan beklentilerinin olması, uygun öğretim yöntem ve tekniklerini kullanmaması olumsuz öğretmen davranışları olarak kabul edilmektedir. Gözütok (1993) tarafından yapılan bir çalışmada ise öğretmenlerin olumsuz davranışları arasında "tokat atma, tebeşir fırlatma, saç çekme, hakaret etme, müdüre götürme, notla tehdit etme" gibi davranışlar bulunmaktadır. Bununla birlikte, öğretmenin derse geç girme, öğrencileri dersten erken çıkarma, derse gelmeme, sınavları zamanında okumama ve plansız olma gibi davranışları da olumsuz davranış olarak kabul edilmektedir (Ekinci ve Burgaz, 2009).

Literatürde etkili ya da olumlu öğretmen davranışlarına yönelik çok sayıda çalışmanın (Bayraktar ve Çınar, 2010; Can, 2004; Dilekman, 2008; Karakelle, 2005; Kızıltepe, 2002; Özkan ve Arslantaş, 2013; Özyürek, 2008; Sünbül, 1996; Şahin, 2011) olduğu ancak doğrudan olumsuz öğretmen davranışlarını ele alan sınırlı sayıda çalışmanın bulunduğu söylenebilir. Ayrıca olumsuz öğretmen davranışlarının genel olarak öğrenci veya öğretmen görüşleri doğrultusunda ortaya konulması da yapılan çalışmaların diğer bir sınırlılığıdır. Bu açıdan değerlendirildiğinde konuya daha kapsamlı bakabilmek adına okul yöneticilerinin de görüşlerini almak önemlidir. Bu bağlamda, yukarıda verilen bilgiler ışığında bu çalışmada okul yöneticilerinin görüşlerine göre ortaokullarda görev yapan öğretmenlerin olumsuz davranışlarının belirlenmesi amaçlanmıştır.

\section{Yöntem}

\section{Araştırma Deseni}

Okul yöneticilerinin görüşlerine göre olumsuz öğretmen davranışlarının belirlenmesinin amaçlandığı bu araştırmada nitel araştırma desenlerinden biri olan olgu bilim kullanılmıştır. Olgu bilim araştırma deseni bireyin 
davranışlarını anlamada ve bireyin kendine özgü yaşantısının bilinmesinde kullanılmaktadır. Bu desende farkında olduğumuz fakat ayrıntılı bilgiye sahip olmadığımız olgulara odaklanılmaktadır (Yıldırım ve Şimşek, 2008). Bu araştırmadaki olgu da ortaokullarda görev yapan öğretmenler olarak kabul edilmiştir.

\section{Çalışma Grubu}

Araştırmanın çalışma grubu, Konya ilinde kamu ortaokullarında görev yapan toplam 9 okul yöneticisinden oluşmaktadır. Çalışma grubunun belirlenmesinde kartopu örnekleme ve maksimum çeşitlilik yaklaşımları kullanılmıştır. Ayrıca örneklemin büyüklüğü belirlemede kuramsal örnekleme yaklaşımı dikkate alınmıştır. Katılımcılara ulaşırken araştırmacı tarafından tanınan isimlerden veri toplanmaya başlanmış ve kartopu tekniği ile yeni isimlere ulaşılmıştır. Maksimum çeşitliliği sağlamak için farklı okullarda görev yapan okul yöneticileri, yöneticilik görevleri ve cinsiyetleri açısından çeşitliliği sağlayacak şekilde araştırmaya dâhil edilmiştir. Örneklem büyüklüğüne karar verirken kuramsal örnekleme yaklaşımı benimsenmiş ve yapılan 9 görüşmeden sonra araştırmacı "doyum noktası" na ulaştı̆̆ına (Yıldırım ve Şimşek, 2008) karar vermiştir. Araştırmaya katılan okul yöneticilerinin cinsiyet, yöneticilik görevi, yöneticilikte geçirdiği süre ve eğitim durumlarıyla ilgili bilgiler Tablo 1'de gösterilmektedir.

Tablo 1. Katılımcılarnn Cinsiyet, Yöneticilik Görevi, Yöneticilik Görev Süresi ve Ĕ̆itim Durumlarına Göre Dağılımı

\begin{tabular}{lllll}
\hline Katılımc1 Sırası & Cinsiyet & $\begin{array}{l}\text { Yöneticilik } \\
\text { Görevi }\end{array}$ & $\begin{array}{l}\text { Yöneticilik } \\
\text { Görev Süresi }\end{array}$ & $\begin{array}{l}\text { Eğitim } \\
\text { Durumu }\end{array}$ \\
\hline K1 & Kadın & Müdür Yrd. & 5 & Yüksek Lisans \\
\hline K2 & Kadın & Müdür Yrd. & 2 & Lisans \\
\hline K3 & Erkek & Müdür & 13 & Lisans \\
\hline K4 & Erkek & Müdür Yrd. & 11 & Lisans \\
\hline K5 & Erkek & Müdür & 8 & Yüksek Lisans \\
\hline K6 & Erkek & Müdür & 4 & Lisans \\
\hline K7 & Erkek & Müdür Yrd. & 4 & Yüksek Lisans \\
\hline K8 & Kadın & Müdür Yrd. & 2 & Lisans \\
\hline K9 & Erkek & Müdür Yrd. & 17 & Lisans \\
\hline
\end{tabular}


Tablo 1'de görüldüğü üzere katılımcıların 3'ü kadın okul yöneticisi, 6'sı erkek okul yöneticisidir. Kadın okul yöneticileri müdür yardımcilı̆̆ görevini yürütürken; erkek okul yöneticilerinden 3'ü müdür, 3'ü de müdür yardımcılığı görevlerini devam ettirmektedirler. Araştırmaya katılan yöneticilerin 3 'ü yüksek lisans mezunu iken diğerleri lisans mezunudur. Okul yöneticileri yöneticilikte geçirdikleri süreler bakımından değerlendirildiğinde ise 5 yöneticinin görev süresinin $0-5$ yıl olduğu, 1 yöneticinin görev süresinin 6-10 yıl olduğu ve 3 yöneticinin görev süresinin 11 yıl ve üzerinde olduğu görülmektedir.

\section{Verilerin Toplanması}

Araştırmanın verileri 2017-2018 eğitim-öğretim yılında Konya ilinde bulunan kamu ortaokullarında görev yapan okul yöneticilerinden toplanmıştır. Veriler, araştırmacı tarafından geliştirilen yarı yapılandırılmış görüşme formu ile toplanmıştır. Görüşme soruları olumsuz öğretmen davranışlarıyla ilgili alan yazın taraması yapılarak hazırlanmışır. Görüşmeler bütün katılımcılarla yüz yüze ve araştırmacı tarafından gerçekleştirilmiş olup katılımcı izniyle kaydedilmiş ve kayıtlar yazılı metne dönüştürülmüştür. Bu kapsamda 12 sayfa görüşme metni çıkarılmıştır.

\section{Verilerin Analizi}

Araştırmada veriler içerik analizi tekniğinden yararlanılarak analiz edilmiş ve yorumlanmıştır. Bu bağlamda öncelikle görüşme formlarından elde edilen veriler bilgisayar ortamına aktarılmış ve ham veriler düzenlenmiştir. Bu veriler daha sonra araştırmanın amacı doğrultusunda tematik bir yaklaşımla analiz edilerek yorumlanmıştır. Araştırmada doğrudan alıntı yapılan katılımcı görüşleri italik biçimde gösterilerek katılımcı kodları parantez içinde sunulmuştur.

\section{Bulgular}

Araştırma kapsamında, öğretmenlerin olumsuz davranışlarını belirlemeye yönelik katılımcılara ilgili alan yazın taraması da dikkate alınarak 4 
soru yöneltilmiştir. Birinci soru öğretmenlerin öğrenci öğrenmelerini güçleştiren özelliklerini ortaya çıkarmaya yönelik iken ikinci soru öğretmenlerin sınıf yönetimiyle ilgili sahip oldukları olumsuz davranışlara odaklanmaktadır. Diğer taraftan, öğretmenlerin rehberlik faaliyetleriyle ilgili olumsuz davranışları 3. soru ile ölçme ve değerlendirmeyle ilgili olumsuz davranışları ise 4. soru ile belirlenmeye çalışılmıştır.

Öğrenci öğrenmelerini güçleştiren öğretmen davranışlarına yönelik katılımcı görüşlerinden elde edilen bulgulara Tablo 2'de yer verilmektedir.

Tablo 2. Öğrenci Öğrenmelerini Güçleştiren Öğretmen Davranışlarına İlişkin Bulgular

\begin{tabular}{|c|c|c|}
\hline Temalar & Alt Temalar & Görüş (f) \\
\hline $\begin{array}{l}\text { Mesleki } \\
\text { Özellikler }\end{array}$ & $\begin{array}{ll}\text { - } & \text { Yapılandırmacı yaklaşım yerine geleneksel yaklaşım yön- } \\
& \text { temlerini kullanmaları (K1,2 MY, K3 M) } \\
\text { - } & \text { Ezbere dayalı eğitim yapmaları (K1 MY) } \\
\text { - } & \text { Bireysel farklılıkları dikkate almamaları (K1 MY, K3 M) } \\
\text { - } & \text { Alanlarındaki gelişmeleri takip etmemeleri ve kendilerini } \\
\text { - } & \text { Derse hazırılık yapmadan katılmaları (K3 M, K8 MY) } \\
\text { - } & \text { Öğrencileri güdülememeleri (K3 M, K8 MY) } \\
\text { - } & \text { Konuya ve öğrenciye uygun yöntem ve teknikleri kullanma- } \\
& \text { maları (K5 M, K4,7,8,9 MY) } \\
\text { - } & \text { Yeni yöntem ve teknikler hakkında yeterli bilgiye sahip ol- } \\
& \text { mamaları (K7,8 MY) } \\
\text { - } & \text { Öğrencilerin hazırbulunuşluk düzeylerini dikkate almama- } \\
& \text { ları (K5 M, K4,9 MY) } \\
\text { - } & \text { Öğrencilerin dikkat sürelerini dikkate almamaları (K8 MY) } \\
\text { - } & \text { Araştırmaya dayalı ödev vermemeleri (K8 MY) } \\
& \text { Mesleklerini severek ve isteyerek yapmamaları (K9 MY) } \\
\end{array}$ & 27 \\
\hline $\begin{array}{l}\text { Kişisel } \\
\text { Özellikler }\end{array}$ & $\begin{array}{ll}\text { - } & \text { Öğrencilere karşı önyargılı davranmaları (K5 M) } \\
\text { - } & \text { Aşırı sert veya aşırı yumuşak tutumları (K6 M) } \\
\text { - } & \text { Öğrencilere karşı ilgisiz tavırları (K6 M) } \\
\text { - } & \text { Öğrencilerle doğru iletişim kurmamaları (K7 MY) } \\
\text { - } & \text { Profesyonel davranmamaları (K7,8 MY) } \\
\text { - } & \text { Öğrencileri aşağılamaları, hakaret etmeleri (K8 MY) }\end{array}$ & 7 \\
\hline
\end{tabular}

Tablo 2'deki veriler incelendiğinde, okul yöneticilerinin görüşlerine göre öğretmenler daha çok mesleki özelliklerinden ( $\mathrm{f}=27$ ) dolayı öğrencilerin öğrenmelerini güçleştirmektedir. Okul yöneticileri öğrenci öğrenme- 
lerini güçleştiren davranışlar kapsamında öğretmenlerin geleneksel yöntem ve teknikleri kullanmalarını, kendilerini geliştirmemelerini, derse hazırlıksız gelmelerini, mesleklerini severek yapmamalarını ve öğrencilerin bireysel farklılıklarına, hazırbulunuşluklarına ve dikkat sürelerine gereken önemi vermemelerini olumsuz davranış olarak değerlendirmişlerdir. Buna göre, bir müdür yardımcısı "Pek çok öğretmen geleneksel yaklaşımı, ezbere dönük anlatımı kullanmaya devam etmektedir. Oysa yapılandırmacı yaklaşım öğrencilerin yaparak yaşayarak ve sorgulayarak öğrenmelerini, bilgiye araştırarak ulaşmalarını sağlamakta ve bu yaklaşımda öğrenme daha kahıcı hale gelmektedir (K1 MY)." şeklinde görüş belirtmiştir. 11 yıllık bir müdür yardımcısının görüşü ise şöyledir: "Öğretmenlerin anlatacakları konuyu uygun yöntem ve tekniklerle işleyememeleri, ögrencilerin ön bilgilerini, hazır bulunuşluklarını dikkate almamaları, konuyu yeterince somutlaştıramamaları öğrencilerin öğrendiklerini anlamlandıramamalarına neden olmaktadır. Bazı öğretmenler teknolojiyi takip etme konusunda oldukça yetersiz. Akıll tahta, bilgisayar, internet gibi teknolojik ürünlerin kullanımında sıkıntı yaşıyorlar. Hâlbuki bazı konuların uzun uzun anlatılmasina, soyut düzlemde kalmasina gerek yok. Bu konular teknolojik ürünlerin yardımıyla kolaylıkla öğretilebilir (K4 MY)." Bu bağlamda, yöneticilerin özellikle alan bilgisi ve öğretmenlik meslek bilgisi konularında, öğretmenlerin sahip olduğu olumsuz davranışların öğrenci öğrenmelerini güçleştirdiğine inandıkları söylenebilir.

Tablo 2' deki verilere göre, öğretmenlerin profesyonel olmama, yanlış tutum sergileme, öğrencilere karşı ön yargılı veya ilgisiz davranma, öğrencileri aşağılama, hakaret etme ve onlarla doğru iletişim kurmama gibi kişisel özellikleri ( $f=7$ ) de yönetici görüşlerine göre öğrenci öğrenmelerini güçleştirebilen olumsuz davranışlar arasındadır. Örneğin, bir müdür yardımcis1 "Öğretmenlerin pedagojik anlamda eksiklikleri, öğrencilerle doğru iletişim kurmamaları, profesyonel davranmamaları, eksikliklerini ya da öğrencilerin eleştirilerini kabul etmemeleri öğrencilerin öğrenmelerini zor hale getirmektedir (K7 MY)." şeklinde görüş belirtmiştir. Diğer taraftan bir başka müdür yardımcısı, "Öğretmenler öğrencileri aşă̆ıladıklarında veya hakaret ettiklerinde onların derslere ve öğrenmeye karşı olumsuz tutum geliştirmelerine neden olmaktadır. Bu durum öğrenmenin gerçekleşmesine engel olmaktadır. Bu anlamda öğretmen profesyonel davranmal ve bir takım olumsuz kişilik özelliklerini mesleğinin önüne çıkarmamalıdır (K8 MY)." şeklinde görüşünü ifade etmiştir. Bu görüşlere göre, okul yöneticilerinin öğretmenlik mesleğini profesyonel bir iş 
olarak gördüklerini ve öğretmenlerin öğrenci öğrenmelerini güçleştirecek olumsuz kişisel özelliklerinden rahatsızlık duyduklarını söylemek mümkündür.

Öğrencilerin derse karşı motivasyonunu, tutumunu ve derse katılımını olumsuz yönde etkileyen öğretmen davranışlarına yönelik yönetici görüşlerinden elde edilen bulgular Tablo 3'de verilmektedir.

Tablo 3. Öğrencilerin Derse Karşı Motivasyonunu, Tutumunu ve Derse Katılımını Olumsuz Yönde Etkileyen Öğretmen Davranışlarına Yönelik Bulgular

\begin{tabular}{|c|c|c|}
\hline Temalar & Alt Temalar & Görüş (f) \\
\hline $\begin{array}{l}\text { Sinıf Yönetimi } \\
\text { (Öğretim) }\end{array}$ & $\begin{array}{ll}\text { - } & \text { Dersin planlanmasını ve plana göre yürütülmesini } \\
\text { - } & \text { Sağlamamaları (K3 M) } \\
\text { - } & \text { Sinav sonuçlarını zamanında açıklamamaları (K3 M) } \\
& \mathrm{M}) \\
\text { - } & \text { Sınavda yapılın öğrencilere kontrol ettirmemeleri (K3 } \\
& \mathrm{M}) \\
\text { - } & \text { Öğrenciyi derse katılımı konusunda cesaretlendirme- } \\
& \text { meleri (K4 MBY, K6 M, K8 MY) } \\
\text { - } & \text { Dersi ilgi çekici hale getirmemeleri (K5,6 M, K8,9 MY) } \\
\end{array}$ & 11 \\
\hline $\begin{array}{l}\text { Sinıf Yönetimi } \\
\text { (Bireysel } \\
\text { Özellikler) }\end{array}$ & $\begin{array}{ll}\text { - } & \text { Notu tehdit edici araç olarak kullanmaları (K1 MY) } \\
\text { - } & \text { Aşırı sert veya aşırı yumuşak davranışları (K1,2,7,9 } \\
& \text { MY, K4 MBY) } \\
\text { - } & \text { Öğrencinin kişiliğine saygı duymamaları (K4 MBY, K7 } \\
& \text { MY) } \\
\text { - } & \text { Sadece başarılı̈ öğrencilere odaklanıp diğer öğrencileri } \\
& \text { ihmal etmeleri (K4 MBY, K5 M) } \\
\text { - } & \text { Öğrencilerin bireysel farklılıklarını dikkate almama- } \\
& \text { ları (K5 M) } \\
\text { - } & \text { Öğrencilere karşı adil olmamaları (K7 MY) }\end{array}$ & 12 \\
\hline $\begin{array}{l}\text { Sinıf Yönetimi } \\
\text { (Disiplin) }\end{array}$ & $\begin{array}{l}\text { - Sınıfta istenmeyen öğrenci davranışlarını önleyeme- } \\
\text { meleri (K6 M) }\end{array}$ & 1 \\
\hline
\end{tabular}

Tablo 3'deki veriler incelendiğinde, yönetici görüşlerine göre öğretmenler daha çok sınıf yönetiminin bireysel özellikler ve öğretim boyutunda öğrencilerin derse karşı motivasyonunu, tutumunu ve derse katıl1mını olumsuz yönde etkilemektedirler. Sınıf yönetiminin öğretim boyutunda ( $\mathrm{f}=11)$, okul yöneticileri öğretmenlerin dersin planlanmasını ve plana göre yürütülmesini sağlamamalarını, sınav sonuçlarını zamanında açıklamamalarını, sınav kâğıtlarını öğrencilere kontrol ettirmemelerini, s1- 
navda yapılan yanlışlar üzerinde durmamalarını, öğrencileri derse katılımları konusunda cesaretlendirmemelerini ve dersi ilgi çekici hale getirmemelerini olumsuz davranış olarak değerlendirmişlerdir. Buna göre bir müdür, “Öğretmenlerin dersin bir planın dönem başında sunmamaları, yazılı tarihlerini önceden sisteme girmemeleri, sınav sonuçlarım zamanında açıklamamaları, cevap kâğıtlarını öğrencilere kontrol ettirmemeleri gibi davranışları öğrencilerin motivasyonunu düşürmektedir. Ayrıca öğretmen sınavda yapılan yanlışlar üzerinde durmadıklarında öğrenciler bu soruların cevaplarını öğrenemediklerinden zamanla derse karşı ilgilerini kaybetmektedirler (K3 M)." şeklinde görüş bildirmiştir. Bir başka okul müdürü ise "Öğretmenin dersi tek düze bir şekilde anlatması öğrencilerin derse karşı ilgilerini azaltmaktadır. Öğretmen ders anlatırken farklı ses tonu ve mimikleri kullanarak ders anlatsa ve öğrencileri derse katılımları konusunda cesaretlendirse öğrenciler de derse karşı olumlu bir tutum geliştireceklerdir (K6 M)." şeklinde görüşünü ifade etmiştir.

Tablo 3'deki verilere göre, öğretmenlerin notu tehdit edici araç olarak kullanmaları, aşırı sert veya aşırı yumuşak davranışları, öğrencinin kişiliğine saygı duymamaları, sadece başarılı öğrencilere odaklanıp diğer öğrencileri ihmal etmeleri, öğrencilerin bireysel farklılıklarını dikkate almamaları, öğrencilere karşı adil olmamaları sınıf yönetiminin bireysel özellikler boyutunda $(\mathrm{f}=12)$ yer alan ve öğrencilerin derse karşı motivasyonunu olumsuz yönde etkileyen davranışlar arasındadır. Okul yöneticileri öğretmenlerin sınıfta istenmeyen öğrenci davranışlarını önleyememelerini ise sinıf yönetiminin disiplin boyutunda $(\mathrm{f}=1)$ yer alan olumsuz öğretmen davranışları olarak değerlendirmişlerdir. Konuyla ilgili olarak bir müdür yardımcısı "Öğretmenlerin öğrencilerin kişiliğini önemsememesi ve fikirlerinden dolayı ayıplaması öğrencinin derse yönelik olumsuz tutum geliştirmesine neden olmaktadır. Ayrıca öğretmenler kimi zaman bazı öğrencilere çok fazla ilgi göstererek bazı öğrencileri görmezden gelmektedir. Bu durumda bu öğrenciler kendilerini değersiz hissetmekte ve ne yaparlarsa yapsinlar öğretmenin kendilerine söz hakkı vermeyeceğini, ilgi göstermeyeceğini düşünmektedirler. Bu da öğrencilerin dersten dişlanmasına ve derste motivasyonlarının düşmelerine yol açmaktadır. Diğer taraftan, öğretmenin sinıfta otoriter bir tavır içinde olması da öğrenciler üzerinde olumsuz etki yaratmaktadır. Bu öğretmenler öğrencilerin sürekli kaygılı olmalarına neden olmaktadır. Öğretmeninden korkan, çekinen bir öğrencin derse olumlu tutum geliştirmesi mümkün değildir (K4 MY)." şeklinde görüşünü ifade etmiştir. Sınıf yönetiminin disiplin boyutuna ilişkin bir 
okul müdürünün görüşü ise şu şekildedir: “Öğgretmenin sınıfta disiplini să̆layamaması, olumsuz davranışları olan öğrencileri kontrol edememesi diğer öğrenciler açısından sorunlara yol açmaktadır. Bu öğrenciler dersi ve öğretmeni önemsememeye başlamakta ve motivasyonları düşmektedir (K6 M)."

Öğrencilerin olumsuz duygular yaşamasına ve dolayısıyla öğrenci-öğretmen arasındaki ilişkilerin bozulmasına neden olan öğretmen davranışlarına yönelik katılımcı görüşlerinden elde edilen bulgular Tablo 4 'te verilmektedir.

Tablo 4. Öğrencilerin Olumsuz Duygular Yaşamasına ve Öğrencilerle Olan İlişkilerin Bozulmasına Neden Olan Olumsuz Öğretmen Davranışlarına Yönelik Bulgular

\begin{tabular}{|c|c|c|}
\hline Temalar & Alt Temalar & Görüş (f) \\
\hline $\begin{array}{l}\text { Olumlu } \\
\text { İletişim } \\
\text { Kuramama }\end{array}$ & $\begin{array}{ll}\text { - } & \text { Öğrencilerle sağlıklı iletişim kuramamaları (K1,7,9 MY, K3 } \\
& \mathrm{M}) \\
\text { - } & \text { Şiddet içeren davranışlarda bulunmaları (K4 MY, K5 M) } \\
\text { - } & \text { İlgisiz davranmaları (K5 M) } \\
\text { - } & \text { Olumlu öğrenci davranışlarını takdir etmemeleri (K5 M) } \\
\text { - } & \text { Öğrencilerin sorularını kızarak cevaplamaları (K7,8,9 MY) }\end{array}$ & 11 \\
\hline $\begin{array}{l}\text { Öğrenciler } \\
\text { Arasında } \\
\text { Eşit Dav- } \\
\text { ranmama }\end{array}$ & $\begin{array}{ll}\text { - } & \text { Öğrenciler arasında adaleti sağlayamamaları (K1,2,4 MY) } \\
\text { - } & \text { Öğrenciler arasında ayrımcllı yapmaları (K3 M, K4,7,8 MY) } \\
\text { - } & \text { Öğrencileri sadece akademik başarılarına göre değerlendir- } \\
& \text { meleri (K8 MY) }\end{array}$ & 8 \\
\hline $\begin{array}{l}\text { Öğrencinin } \\
\text { Kişiliğine } \\
\text { Sayg1 Duy- } \\
\text { mama }\end{array}$ & $\begin{array}{ll}\text { - } & \text { Öğrencilerin davranışlarını değil kişiliklerini hedef almaları } \\
\text { (K2,4,7 MY, K3,5,6 M) } \\
\text { - } \quad \text { Öğrencilerin özel bilgilerini sınıfta paylaşmaları (K6 M) }\end{array}$ & 7 \\
\hline $\begin{array}{l}\text { Kişisel } \\
\text { Sorunlar }\end{array}$ & $\begin{array}{ll}\text { - } & \text { Tutarsız davranmaları (K1 MY) } \\
\text { - } & \text { Kişisel problemlerini öğrencilere yansıtmaları (K4 MY) } \\
\end{array}$ & 2 \\
\hline
\end{tabular}

Tablo 4'teki veriler incelendiğinde, okul yöneticilerinin görüşlerine göre öğretmenlerin daha çok olumlu iletişim kuramama ( $\mathrm{f}=11$ ), öğrenciler arasında eşitliği sağlayamama $(\mathrm{f}=8)$ ve öğrencilerin kişiliğine saygı duymama ( $\mathrm{f}=7)$ özelliklerinden dolayı öğrenciler olumsuz duygular yaşamakta ve öğretmenleriyle ilişkileri bozulmaktadır. Olumlu iletişim kuramama boyutuyla ilgili olarak okul yöneticileri öğretmenlerin öğrencilerle sağlıklı iletişim kuramamalarını, şiddet içeren davranışlarda bulunmalarını, ilgisiz davranmalarını, olumlu öğrenci davranışlarını takdir etmemelerini ve öğrencilerin sorularını kızarak cevaplamalarını olumsuz davranış olarak değerlendirmişlerdir. Buna göre, bir okul müdürü “Öncelikle bir öğretmen öğrenciyi disipline etmek adına şiddete başvurduğunda veya şiddete, 
hakarete dayalı söylemlerde bulunduğunda öğrencinin o öğretmene karşı olumsuz duygular beslemesi kaçınılmazdır. Bunun dışında bazı öğretmenler öğrencilerine karşı çok kayıtsız olabilmektedir. Öğretmenliği sadece bir iş olarak gören bu öğretmenler maalesef öğrencileri kendilerinden soğutmaktadır. Örneğin olumlu davranış sergileyen veya başarılı olmak için sürekli çabalayan bir öğrenciyi eğer öğretmen sürekli görmezden geliyor ve takdir etmiyorsa bu öğrencinin de olumsuz duygular yaşaması kaçınılmazdır (K5 M)."

Tablo 4'teki bulgulara göre, okul yöneticilerinin görüşlerine göre öğretmenlerin öğrenciler arasında adaleti sağlayamamaları, ayrımcılık yapmaları ve onları sadece akademik başarılarına göre değerlendirmeleri öğrenciler arasında eşitliği sağlayamama özelliklerinden kaynaklanan olumsuz davranışlarıdır. Buna göre bir müdür yardımcısı “Öğretmen öğrenciler arasında ayrımcılık yapıyorsa -bazı öğrenciler mutlak sorunlu iken bazı öğrenciler mutlak manada mükemmel ise-bu da öğrencilerin olumsuz duygular yaşamasina sebep olacaktır. Öğretmenin çocuklar arasında adil davranması gerekmektedir. Bu adalet anlayışı gerek ödüllendirmede gerekse yaptırım uygulamada herkese eşit olmalıdır (K4 MY)." şeklinde görüşünü ifade ederken başka bir müdür yardımcısı "Her öğrencinin akademik anlamda başarılı olmasın bekleyemeyiz. Derslerinde başarısız bir öğrenci ilgi ve yetenekleri doğrultusunda farkh alanlarda kendini gösterebilir. Dolayısıyla bu tür öğrencileri de sırf derslerinde başarısız diye dışlamak veya buna göre değerlendirmek doğru değildir. Bu durum öğrencilerin derse ve öğretmene karşı olumsuz duygular beslemesine neden olabilir (K8 MY)." şeklinde görüş belirtmiştir. Bu görüşlere göre, okul yöneticilerinin öğrencilerin olumsuz duygular yaşamasını önlemeye yönelik öğretmenlik mesleğinde öğrenciler arasında eşitliğin ve adaletin sağlanması konusuna vurgu yaptıkları görülmektedir.

Tablo 4'teki bulgular incelendiğinde, okul yöneticilerinin görüşlerine göre öğretmenlerin davranışlar yerine öğrencilerin kişiliklerini hedef almaları ve öğrencilere yönelik özel bilgileri sınıfta paylaşmaları ise kişiliğe saygı duymamaktan kaynaklanan olumsuz öğretmen davranışlarıdır. Buna göre bir müdür yardımcısı “Öğretmenin bir öğrencisini sınıf içerisindeki olumsuz davranışından dolayı arkadaşları önünde küçük düşürmesi, alay etmesi veya hakaret etmesi öğrenci açısından unutulması zor bir durumdur. Öğrenci direk kişiliğini hedef alan öğretmenini doğal olarak sevmez ve kendisine karşı sürekli olumsuz duygular besler (K7 MY)." şeklinde görüş bildirmiştir. Bir okul müdürünün görüşü ise şu şekildedir: "Öğretmen öğrencilerin özel hayatlarının 
gizliliği konusunda gereken hassasiyeti gösterebilmelidir. Nedeni ne olursa olsun öğrencilerin bir takım özel bilgileri sınıfta paylaşılmamalıdır. Aksi takdirde bu durum öğrencinin öğretmene karşı olumsuz duygular beslemesine yol açar ve aralarında aşılması zor iletişim engelleri ortaya çıkar (K6 M)."

Tablo 4'teki bulgulara göre, bazı okul yöneticileri ise öğretmenlerin tutarsız davranışlarını ve kişisel problemlerini öğrencilere yansıtmalarını kişisel sorunlardan kaynaklı ( $\mathrm{f}=2$ ) olumsuz öğretmen davranışı olarak değerlendirmişlerdir. Buna göre, bir müdür yardımcısı “Öğretmenin öğrencinin velisiyle olan sıkıntıların öğrenciye yansıtması öğrencinin olumsuz duygular yaşamasına neden olmaktadır. Benzer şekilde, öğrenci velisiyle çok iyi ilişkileri olan bir öğretmenin bu ilişkisini o öğrencinin lehine ayrıcalıklı kullanması da diğer öğrencilerin olumsuz duygular yaşamasına neden olabilmektedir. Bu noktada öğretmen-veli ilişkilerinin boyutu ne olursa olsun (iyi veya kötü) bunun öğrenciye yansıması konusunda öğrencinin yüksek yararı göz önünde tutulmalıdır (K4 $M Y)$." şeklinde görüşünü ifade etmiştir.

Tablo 4'teki bulgular genel olarak değerlendirildiğinde, okul yöneticilerinin öğrencilerle olumlu iletişim kuramama, öğrenciler arasında eşitliği sağlayamama, öğrencilerin kişiliğine saygı duymama ve kişisel sorunlara sahip olma gibi olumsuz öğretmen davranışlarından dolayı öğrencilerin duygusal açıdan olumsuz etkilendiklerini düşündükleri söylenebilir.

Katılımcıların ölçme ve değerlendirme süreciyle ilgili olumsuz öğretmen davranışlarına yönelik görüşlerinden elde edilen bulgular Tablo 5'te verilmektedir.

Tablo 5'teki bulgulara göre, okul yöneticilerinin görüşlerine göre öğrencilerin derse ilişkin başarısını değerlendirmeye yönelik öğretmenlerin daha çok ölçme $(\mathrm{f}=10)$ ve değerlendirmeyle $(\mathrm{f}=11)$ ilgili sahip oldukları olumsuz davranışları başarının tam olarak yansıtılmasını engellemektedir. Ölçme açısından bakıldığında, okul yöneticileri öğretmenlerin puan ölçütlerini önceden hazırlayıp bildirmemelerini, sınavlarda kapsam geçerliliğine dikkat etmemelerini, işlenen konulara uygun sorular hazırlamamalarını, kolay ve hızlı değerlendirilebilen sınavlar hazırlamayı tercih etmelerini ve yeterince açık olmayan, anlaşılması zor sınavlar hazırlamalarını olumsuz davranışlar olarak değerlendirmektedirler. Buna göre, bir müdür yardımcısı "Öğrenci başarılarının değgerlendirilmesindeki en önemli nokta geçerli ve güvenilir ölçme araçlarının hazırlanmasıdır. Özellikle kapsam geçerliliğine dikkat edilmemesi okullarda öğretmenlerin yaptı̆̆̆ ölçme hatalarının 
Tablo 5. Öğrencilerin Başarıların Yansıtmasını Engelleyen Olumsuz Öğretmen Davranışlarına Yönelik Bulgular

\begin{tabular}{|c|c|c|}
\hline Temalar & Alt Temalar & Görüş (f) \\
\hline Ölçme & $\begin{array}{ll}\text { - } & \text { Puan ölçütlerini önceden hazırlayıp bildirmemeleri (K2 MY, } \\
& \text { K3 M) } \\
\text { - } & \text { Sınav sorularının açı olmaması (K3 M) } \\
\text { - } & \text { Sinavlarda kapsam geçerliliğine dikkat etmemeleri (K3,6 M, } \\
& \text { K4,7 MY) } \\
\text { - } & \text { Konuya uygun sorular hazırlamamaları (K4 MY) } \\
\text { - } & \text { Kolay ve hızlı değerlendirilebilen sinavlar hazırlamaları (K5 } \\
\text { M) } \\
\text { - Soruları hazırlarken bireysel farklılıkları dikkate almamaları } \\
\text { (K5 M) }\end{array}$ & 10 \\
\hline $\begin{array}{l}\text { Değer- } \\
\text { lendirme }\end{array}$ & 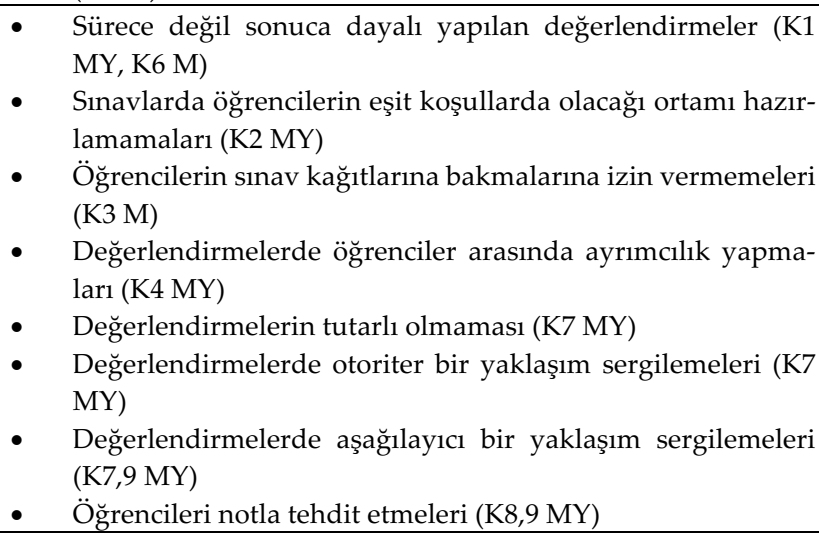 & 11 \\
\hline
\end{tabular}

başında gelmektedir. Bu durumda öğrenciler sorumlu olmadıkları konulardan değerlendirmeye tutulduklarından başarıların tam olarak yansıtamamaktadır. Ayrıca konuların türüne uygun soru tarzlarının sorulmaması da öğretmenlerin en fazla yaptıkları hatalar arasında yer almaktadır (K4 MY)." şeklinde görüşünü ifade etmiştir. Benzer şekilde bir okul müdürü de "Öğrencinin başarısını yansıtmasını engelleyen en önemli faktör bence kullanılan araçların yetersizliğidir. Yazılı ya da alternatif değerlendirme araçlarında öğrencinin tam olarak performansını göstermesini sağlayacak soruların sorulmaması, değerlendirme uygulamalarında tercih edilen soru tiplerinin kolay ve hızh değerlendirilebilen türden seçilmeleri, bireysel farklllıkların dikkate alınmaması gibi birçok hususu burada örnek verebiliriz (K5 M)." şeklinde görüş belirtmiştir.

Tablo 5'e göre değerlendirme süreciyle ilgili okul yöneticilerinin, sürece değil sonuca dayalı değerlendirmeler yapılmasını, öğrencilere eşit 
koşulların sağlandığı sınav ortamlarının sunulmamasını, sınav kâğıtlarının kontrolüne yönelik öğrenciye izin verilmemesini, değerlendirmelerde öğrenciler arasında ayrımcılık yapılmasını veya tutarsız davranılmasını, otoriter veya aşağılayıcı bir yaklaşımla değerlendirme yapılmasını ve öğrencilerin notla tehdit edilmesini olumsuz öğretmen davranışları arasında değerlendirdikleri görülmektedir. Buna göre, bir müdür yardımcısı, "Yazılı veya sözlü sınavlar öğrencilerin başarısını tam olarak yansıtmayabilir. Zira bazı öğrenciler sinavlarda heyecanlanmakta ve bildiklerini yansıtamadıkları için hak ettikleri düzeyde başarılı olamamaktadır. O nedenle anlık değerlendirmeler yerine sürecin değerlendirilmesinin daha doğru olacă̆ını düşünüyorum (K1 MY)." şeklinde görüşünü belirtmiştir. Bir başka müdür yardımcısı ise "Öğretmenlerin değerlendirme sürecinde farkl zamanlardaki benzer davranışlara ya da cevaplara farklı tepkiler vermesi, korkutucu veya alaycı bir yaklaşım sergilemeleri, tek otorite olarak kendilerini görmeleri, söylemleri ile uygulamaları arasında tutarsızlık davranmaları öğrencilerin başarılarını yansıtmalarında engel teşkil etmektedir (K7 MY)." şeklinde görüşünü ifade etmiştir.

\section{Tartışma ve Sonuç}

Okul yöneticilerinin görüşlerine göre ortaokullarda görev yapan öğretmenlerin olumsuz davranışlarının belirlenmesi amacıyla yapılan bu çalışmada, eğitim-öğretim süreçleri kapsamında öğrenci öğrenmelerini güçleştiren, sınıf yönetimi kapsamında öğrencilerin derse karşı motivasyonlarını, tutumlarını ve katılımlarını olumsuz yönde etkileyen, rehberlik kapsamında öğrencilerin olumsuz duygular yaşamalarına neden olan ve son olarak başarının değerlendirilmesi kapsamında öğrencilerin başarılarını tam olarak yansıtmalarını engelleyen davranışlar yöneticiler tarafından olumsuz öğretmen davranışları olarak ifade edilmiştir.

Çalışmadan elde edilen bulgulara göre, öğrenci öğrenmelerini güçleştiren özellikler kapsamında okul yöneticilerinin en çok öğretmenlerin mesleki özelliklerine odaklandıkları ortaya çıkmıştır. Yönetici görüşlerine göre öğretmenlerin öğrencilerin hazırbulunuşluk düzeylerini dikkate almamaları, derslerde uygun yöntem ve teknikleri kullanmamaları, geleneksel yöntemleri tercih etmeleri ve dolayısıyla kendilerini geliştirmemeleri öğrenci öğrenmelerini güçleştiren en önemli olumsuz davranışlar ara- 
sındadır. Bu bulgular, alan yazında konuyla ilgili yapılmış farklı araştırmaların bulgularıyla paralellik göstermektedir. Örneğin; Yıldırım ve Akan'ın (2018) çalışmasında öğretmenlerin öğrencilerin ilgi ve isteklerini dikkate almadan yoğun bir şekilde sadece konuların aktarılmasıyla ilgilenmeleri öğrenciler tarafından olumsuz öğretmen davranışları olarak değerlendirilmiştir. Konuyla ilgili olarak Karakelle ve Canpolat (2008) tarafından yapılan çalışmada bilhassa tükenmişlik duygusu yaşayan öğretmenlerin öğrenci-öğretmen etkileşimini yalnızca ders ve not kapsamında değerlendirmeyi tercih ettikleri belirtilmektedir.

Gençtanırım ve diğerleri (2014) tarafından yapılan çalışmada öğrencilerin ders konularını etkili bir şekilde öğrenebilmeleri için öğretmenlerin uygun yöntemleri kullanmaları gerektiği sonucuna ulaşılmıştır. Erden'e (2000) göre, öğretim yöntem ve tekniklerinin etkililiği konu alanına, öğrenci özelliklerine, kazandırılmak istenilen hedeflere ve öğretmene göre değişmektedir. Bu yüzden öğretmenlerin kullanacakları yöntem ve teknikleri çok iyi bilmesi ve kullanacağ duruma en uygun olanı seçmesi gerekmektedir. Küçükahmet'e (2004) göre, etkili sınıf yönetimini sağlamayı ve sınıfının başarı düzeyini arttırmayı isteyen öğretmen hazırladığı ders içeriğini öğrencinin beş duyusuna da hitap edecek şekilde sunmalı ve buna paralel olarak öğrencinin düzeyine uygun somut materyallerle desteklemelidir. Yapılandırmacı öğrenme ortamının öğrencilerin akademik başarılarına etkisinin araştırıldığı Özerbaş'ın (2007) çalışmasında yapılandırmacı öğrenme ortamlarında öğrenilen bilgilerin kalıcılığının, geleneksel öğretim yöntemlerinin uygulandığı ortamlara kıyasla daha yüksek olduğu sonucuna ulaşılmıştır. Özgan ve Tekin (2011) tarafından yapılan çalışmada ise öğrencilerin hazırbulunuşluk düzeyleri üzerinde öğretmen davranışlarının etkili olduğu sonucuna ulaşılmıştır.

Öğrencilerin derse karşı motivasyonunu, tutumunu ve derse katılımını olumsuz yönde etkileyen öğretmen davranışlarına yönelik elde edilen bulgular incelendiğinde, öğretmenlerin sınıf yönetimiyle ilgili pedagojik açıdan yetersiz olmaları ve olumsuz bireysel özelliklerinin bu süreçte öğrencilere yansıması okul yöneticileri tarafından dile getirilen olumsuz öğretmen davranışları arasında yer almaktadır. Okul yöneticilerine göre, sınıf yönetiminde dikkat edilmesi gereken en önemli husus öğrencinin derse katılımında öğretmenin motive edici bir tavır sergilemesidir. Ko- 
nuyla ilgili olarak Eryılmaz (2013) tarafından yapılan bir çalışmanın sonucunda, öğrencilerin derse katılmalarında etkili öğretmen özelliklerine ilişkin öğretmenin öğrencilerin kişisel beklentilerine yanıt vermesi, öğretmenin kişilik özellikleri ve öğretmenin dersi işleme yöntemi olmak üzere üç önemli boyut bulunmuştur. Rothman'a (1990) göre, sınıftaki en önemli sorunlarından biri öğrencilerin derse katılmaya motivasyonlarının olmayışıdır. Öğrencilerin derse katılmaya ilişkin motivasyonları yoksa sıkılma, konuya dikkatini verememe, okulda yapılanlar ile gerçek yaşam arasında ilişki kuramama gibi bir takım öğrenme açısından olumsuz durumlar ortaya çıkabilmektedir. Sezer (2018) çalışmasında sınıf yönetiminde öğretmenler tarafından sergilenen olumsuz tutum ve davranışların yıllar geçse de öğrenciler üzerinde olumsuz etkiler bıraktığını ifade etmektedir.

Özan (2009) çalışmasında, derse karşı ilgi ve isteğin her öğrencide aynı olmayacağını bu yüzden öğretmenin mümkün olduğunca derse karşı ilgiyi artırıcı etkinlikler düzenlemesi gerektiğini belirtmektedir. Bu bağlamda Strikwerda-Brown, Oliver, Hodgson, Palmer ve Watts' in (2008) çalışmalarında öğretmenin mizah anlayışının kaliteli olmasına ve etkileşimci bir yapıda öğrencilerle iletişim kurmasına yönelik özellikleri üzerinde durulmaktadır. Çelikten ve diğerlerine (2005) göre de ideal öğretmen hoşgörülü ve objektiftir. İdeal öğretmen kendini geliştirmeye açık olmakla birlikte sınıf yönetiminde öğrenci katılımını esas alan etkinlikleri işe koşma konusunda yeterli donanıma sahiptir. Okul yöneticilerinin görüşlerine göre, öğrencilerin derse karşı motivasyonunu, tutumunu olumsuz yönde etkileyen bir diğer önemli husus öğretmenlerin öğrencilerin bireysel farklılıklarını dikkate almamalarıdır. Bu bulgu, Şentürk (2007) tarafından yapılan çalışmanın bulgularıyla paralellik göstermektedir. Yazar çalışmasında, eğitim ve öğretimin başarılı olması için öğretmenlerin öğrenciler arasındaki bireysel farklılıkları dikkate almaları gerektiğini vurgulamaktadir.

Öğrencilerin olumsuz duygular yaşamasına ve öğretmen-öğrenci ilişkilerinin bozulmasına neden olan öğretmen davranışlarına yönelik bulgular değerlendirildiğinde, öğretmenlerin rehberlik faaliyetleri kapsamında öğrencilerle olumlu iletişim kuramamaları, okul yöneticileri tarafından öğretmenlerde görülen olumsuz davranışların başında gelmektedir. Okul yöneticilerine göre öğretmenlerin şiddet içeren davranışlarda bulunmaları, öğrencilere karşı ilgisiz davranmaları, olumlu öğrenci davranışlarını 
takdir etmemeleri ve öğrencilerin sorularını kızarak cevaplamaları gibi olumsuz özellikleri öğrencileriyle olumlu iletişim kuramamalarından kaynaklanmaktadır.

Alanyazında benzer bulguların ortaya koyulduğu çalışmalar bulunmaktadır. Örneğin; Yıldırım ve Akan'ın (2018) çalışmasında öğrencilerin aynı veya başka sınıftan öğrencilerle kıyaslanması ve öğretmenlerin sadece akademik açıdan başarılı öğrencilerle ilgilenerek diğerlerine ilgi göstermemeleri olumsuz öğretmen davranışları arasında gösterilmektedir. Dilekmen (2011) tarafından yapılan çalışmada öğretmenlerin sergiledikleri en yaygın olumsuz davranış olarak fiziksel ve sözel saldırganlık belirtilmektedir. Pajak'ın (2011) çalışmasında öğretmenlerin öğrencilere karşı umursamaz ve saygısız davranışları olumsuz öğretmen davranışları olarak değerlendirilmektedir. Ateş, Özdemir ve Taneri'nin (2019) çalışmasında ise öğretmenlerin tepkisel sınıf yönetimi modelini benimsemeleri olumsuz davranışlar olarak değerlendirilmektedir. Bu tür öğretmenler s1nıflarında sözel ve fiziksel şiddet gösterme eğilimi göstermektedirler. Öğretmenler sınıf yönetimini sağlarken otoriter bir tavır sergilemekte ve bu kapsamda öğrencilere sert davranma veya onları tehdit etme gibi davranışlarda bulunmaktadırlar. Konuyla ilgili yapılan benzer başka çalışmalarda (Baloğlu, 2009; Gözütok, 1993; Tor ve Sargın, 2005) da öğretmenlerin öğrencileriyle olumlu iletişim kuramamaları olumsuz öğretmen davranışı olarak ele alınmaktadır.

Son olarak öğretmenlerin öğrencileri değerlendirmeye yönelik yaptığ1 ve öğrencilerin başarılarını tam olarak yansıtmalarını engelleyen uygulamalara yönelik bulgular ele alındığında, öğretmenlerin ölçme araçlarıyla ilgili yanlış uygulamalarının okul yöneticileri tarafından olumsuz öğretmen davranışları olarak değerlendirildiği görülmüştür. Okul yöneticilerine göre, öğretmenler soru hazırlama konusunda yeterli bilgiye sahip değildir. Bu nedenle konuya ve öğrencilerin özelliklerine uygun soru hazırlamak yerine kendileri için değerlendirmesi en kolay olan çoktan seçmeli sorulardan oluşan teste dayalı ölçme araçlarını kullanmaktadırlar. Dolayısıyla bu durum öğrencilerin tam olarak başarılarını yansıtmalarına engel olmaktadır. Çalışmadan elde edilen bu bulgu, Çepni ve Azar (1998) tarafından yapılan çalışmanın bulgularıyla örtüşmektedir. Yazarların çalışmasında da benzer şekilde ortaöğretim kurumlarında çalışan fizik öğretmenlerinin etkili soru hazırlamada dikkat etmeleri gereken hususlar 
noktasında yeterli bilgiye sahip olmadıkları saptanmıştır. Aynı çalışmada öğretmenlerin öğrencilerini değerlendirmek amacıyla yaptıkları sınavlarda en fazla bilgi, kavrama ve uygulama düzeyinde sorulara yer verdikleri buna karşılık analiz, sentez ve değerlendirme seviyelerindeki sorulara çok az yer verdikleri veya hiç yer vermedikleri sonucuna ulaşılmıştır.

Özetle olumsuz öğretmen davranışlarının okul yöneticilerin görüşleri alınarak çok yönlü olarak incelendiği bu araştırmada, öğretmenlerin öğrenci öğrenmelerini güçleştiren mesleki özellikleri, öğrencilerin motivasyon, tutum ve derse katılımlarını olumsuz yönde etkileyen sınıf yönetimiyle ilgili olumsuz öğretmen davranışları, öğretmen-öğrenci arasında sağlıklı iletişimin kurulamamasından kaynaklanan ve dolayısıyla öğrencilerin olumsuz duygular yaşamasına neden olan öğretmen davranışları, öğrencilerin başarılarını tam olarak yansıtmasını engelleyen ölçmeye dayalı yanlış uygulamalar bağlamında önemli bulgular elde edilmiştir. Bu bulgulardan yola çıkarak öğrenci odaklı etkili öğrenme ortamlarının oluşturulması ve sürdürülebilmesi için hem kişisel hem de mesleki anlamda kendini geliştirmeye açık öğretmenlere ihtiyaç olduğu söylenebilir. Öğretmenler meslekleri gereği farklı bireysel özelliklere sahip öğrencilerle aynı öğrenme ortamını paylaşmakta ve bu ortamda her bir öğrencinin hem akademik hem de sosyal açıdan gelişim göstermesinde aktif rol oynamaktadır. Bu açıdan değerlendirildiğinde, öğretmenlerin sınıf yönetimi konusundaki yeterliliklerinin ve bu kapsamda derslerde farklı yaklaşım, yöntem ve teknikleri kullanmalarının öğrenmenin gerçekleşmesinde önemli bir yere sahip olduğunu söylemek mümkündür. Öğretmenlerin ayrıca ölçme ve değerlendirme de dahil eğitimin tüm süreçlerinde öğrencilere şeffaf davranmasının, onlara birey olarak değer verip etkili iletişim kurmasının öğrenciler üzerinde olumlu etkileri olacağı söylenebilir. Bu bağlamda, kendilerini değerli hisseden öğrenciler derslere ve öğretmenlerine karşı olumlu yönde tutum geliştirebilir. Bu durum öğrencilerin hem akademik başarılarının artmasına hem de sosyal açıdan gelişmelerine katkı sağlayabilir. 


\title{
EXTENDED ABSTRACT
}

\section{School Principals' Views on Teachers' Negative Behavior}

\author{
* \\ Sevda Katıtaş \\ National Education Ministry
}

Teachers should have certain qualities to be effective in their profession. These qualities may vary depending on the objectives of the education system, the mission of the school, the environment in which the school is located, the expectations of parents, and the vision of principals and teachers (Çelikten, Şanal and Yeni, 2005). Demirel (1999) evaluates the qualities that an effective teacher should have in two dimensions as "personal qualities" and "professional qualities". The author focuses on the characteristics of teachers in terms of personal qualities such as providing motivation, focusing on success and being professional. In terms of professional qualities, technical competencies such as planning of teaching activities, use of teaching methods and techniques, effective communication, classroom management, effective use of time, assessment of learning outcomes and guidance stand out. The personal and professional characteristics that an effective teacher should have undoubtedly have an important role in affecting students' behaviors positively and their cognitive and social development. However, there may be some negative behaviors that teachers exhibit consciously or unconsciously during the education process and hence affect students' development negatively.

It is possible to say that there are many studies on effective or positive teacher behaviors in the literature, but there are limited studies on negative teacher behaviors. In addition, revealing negative teacher behaviors in line with the opinions of students or teachers is another limitation of the studies. In this respect, it is important to get the opinions of the school principals in order to look at the issue more comprehensively. In this context, in the light of the information given above, it was aimed to determine the negative behaviors of teachers working in secondary schools according to the opinions of school principals. 
Phenomenology, one of the qualitative research designs, was used in the study. The case in this study was accepted as teachers working in secondary schools. The study group consisted of nine school principals working in public secondary schools in Konya. Snowball sampling and maximum diversity approaches were used in the determination of the study group. In addition, the theoretical sampling approach was used while determining the size of the sample.

In this study, which was conducted to determine the negative behaviors of teachers working in secondary schools according to the opinions of school administrators, in the context of education-teaching processes, behaviors that make student learning difficult are expressed as negative teacher behaviors by the principals. In the scope of classroom management, the behaviors that negatively affect the motivation, attitudes and participation of students towards the lesson were expressed as negative teacher behaviors by the principals. In the scope of guidance, the behaviors that caused the students to experience negative emotions were stated as negative teacher behaviors by the principals. Finally, within the scope of the assessment of achievement, the behaviors that prevented students from fully reflecting their success were expressed as negative teacher behaviors by the principals.

According to the findings of the study, in the context of the features that make student learning difficult, school principals mostly focus on teachers' professional characteristics. According to principals' views, the most important negative behaviors that make it difficult for students to learn are that teachers do not take into consideration the readiness levels of the students, do not use appropriate methods and techniques in the lessons, prefer traditional methods and therefore do not develop themselves.

When the findings of the teacher behaviors that negatively affect the motivation, attitude and participation of the students are examined, the pedagogical insufficiency of teachers about classroom management and the reflection of negative individual characteristics to students in this process are among the negative teacher behaviors expressed by the school principals. According to the school principals, the most important issue to be considered in classroom management is the teacher's motivating attitude in the participation of the student. 
When we evaluate the findings about teacher behaviors that cause students to experience negative emotions and deteriorate teacher-student relations, one of the most negative behaviors seen by the school principals is the inability of teachers to communicate positively with the students within the scope of the guidance activities. According to the school principals, the negative characteristics of teachers such as showing violent behavior, behaving indifferent towards students, do not appreciating positive student behavior and answering students' questions angrily are due to their inability to communicate positively with their students.

Finally, considering the findings that prevent students from fully reflecting their achievements, it was seen that teachers' misapplications related to measurement tools were evaluated by school principals as negative teacher behaviors. According to school principals, teachers do not have enough information about preparing questions. For this reason, teachers use test-based measurement tools that consist of multiple-choice questions that are most easy to evaluate for themselves rather than preparing questions that are appropriate to the subject and the characteristics of the students. Therefore, this situation prevents students from reflecting their full achievement.

\section{Kaynakça / References}

Ashton, P. T., ve Webb, R. B. (1986). Making a difference: Teachers' sense of efficacy and student achievement. Newyork: Longman Publishing Group.

Ateş, S., Özdemir, E. Ç. ve Taneri, A. (2019). İstenmeyen öğretmen davranışlarına ilişkin öğretmen adaylarının görüşleri. Abant İzzet Baysal Üniversitesi Eğitim Fakültesi Dergisi, 19(1), 37-56.

Balay, R. ve Sağlam, M. (2008). Sınıf içi olumsuz davranışlara ilişkin öğretmen görüşleri. Yüzüncü Yıl Üniversitesi Ĕ̆itim Fakültesi Dergisi, 5(2), 1-24.

Baloğlu, N. (2009). Negative behavior of teachers with regard to high school students in classroom settings. Journal of Instructional Psychology, 36(1), 69-78.

Başar, H. (2003). Sinıf yönetimi. Ankara: Anı Yayıncılık.

Bayraktar, Ş. ve Çınar, D. (2010). Öğretmen adaylarının gözü ile fen ve teknoloji öğretmenlerinin etkili öğretmen davranışlarını gerçekleştirme düzeyleri. Ahi Evran Üniversitesi Ĕ̆itim Fakültesi Dergisi, 11(3), 131-152. 
Bursalıoğlu, Z. (2011). Okul yönetiminde yeni yapı ve davranış. Ankara: Pegem Akademi Yayıncılık.

Can, N. (2004). Öğretmenlerin geliştirilmesi ve etkili öğretmen davranışları. Erciyes Üniversitesi Sosyal Bilimler Enstitüsü Dergisi, 1(16), 103-119.

Celep, C. (2004). Meslek olarak öğretmenlik. Ankara: Anı Yayıncılık.

Çelikten, M., Şanal, M. ve Yeni, Y. (2005). Öğretmenlik mesleği ve özellikleri. Erciyes Üniversitesi Sosyal Bilimler Enstitüsü Dergisi, 19(2), 207-237.

Çepni, S. ve Azar, A. (1998). Lise fizik sınavlarında sorulan soruların analizi. III. Ulusal Fen Bilimleri Ĕ̆itimi Kongresi, 109-114.

Danielson, C. (2007). Enchancing professional practice: A framework for teaching. (2nd ed.) Alexandra, VA: ASCD.

Demirel, Ö. (1999). 21. yüzyıla girerken Türkiye'de öğretmen nitelikleri. Cumhuriyet'in yetmiş beşinci yılında öğretmen yetiştirme. Ankara: Milli Ĕgitim Basim Evi.

Dilekmen, M. (2011). Student teachers' observations of unfavorable teacher behaviors exhibited in classrooms. Psychological reports, 108(1), 45-53.

Dilekman, M. (2008). Etkili eğitim için etkili öğretmenlik. Atatürk Üniversitesi Sosyal Bilimler Enstitüsü Dergisi, 12(2), 213-221.

Ekinci, C. E. ve Burgaz, B. (2009). İstenmeyen öğrenci davranışlarının öğretmen ve okuldan kaynaklanan nedenleri. Sosyal Bilimler Dergisi, 22, 91111.

Erden, M. (2000). Sosyal bilgiler öğretimi. Ankara: Alkım Yayınevi.

Erden, M. (1999). Öğretmenlik mesleğine giriş. Ankara: Alkım Yayınevi.

Eryılmaz, A. (2013). Okulda motivasyon ve amotivasyon: Derse katılmada öğretmenden beklentiler ölçeğinin geliştirilmesi. Mehmet Akif Ersoy Üniversitesi Ĕ̆̈itim Fakültesi Dergisi, 1(25), 1-18.

Gençtanırım, D., Torunoğlu, H. ve Köroğlu, M. (2014). Olumsuz öğretmen davranışlarının çok boyutlu incelenmesi. Uluslararası Avrasya Sosyal Bilimler Dergisi, 5(16), 1-18.

Gözütok, F. D. (1993). Okulda dayak. Ankara Üniversitesi Ĕ̆gitim Bilimleri Yayınları, Ankara.

Karakelle, S. (2005). Öğretmenlerin etkili öğretmen tanımlarının etkili öğretmenlik boyutlarına göre incelenmesi. Ĕ̆itim ve Bilim, 30(135), 1-10.

Karakelle, S. ve Canpolat, S. (2008). Tükenmişlik düzeyi yüksek ilköğretim öğretmenlerinin öğrencilere yaklaşım biçimlerinin incelenmesi. Ĕğitim ve Bilim, 33(147), 106-120.

Kizıltepe, Z. (2002). İyi ve etkili öğretmen. Ĕ̆itim ve Bilim, 27(126), 10-14. 
Kyriakides, L., ve Creemers, B. (2011). The impact of quality of teaching on student outcomes: Implications for policy and practice on teacher professional development. In Conferencia IVALUA, Barcelona, España.

Küçükahmet, L. (2004). Simıf yönetimi. Ankara: Nobel Yayın Dağıtım.

Lewis, R., ve Riley, P. (2009). Teacher misbehaviour. In (L. J. Saha, \& A. G. Dworkin Eds.), The international handbook of research on teachers and teaching (p. 417-431). Norwell, MA, USA: Springer.

Özan, M. B. (2009). Öğretmenlerin uyguladıkları sınıf yönetimi kuralları hakkında öğrenci görüssleri. e-Journal of New World Sciences Academy, 4(2), 1306- 1311.

Özdemir, M. ve Sönmez, S. (2000). Sinıföğretmeni adaylarına öğretmen el kitabı. Ankara: Pegem A Yayınları.

Özerbaş, M. A. (2007). Yapılandırmacı öğrenme ortamının öğrencilerin akademik başarılarına ve kalıcılığına etkisi. Türk Eğitim Bilimleri Dergisi, 5(4), 609-635.

Özgan, H. ve Tekin, A. (2011). Öğrencilerin hazırbulunuşluk düzeylerinin s1nıf yönetimine etkisine yönelik öğretmen görüşleri. Mustafa Kemal Üniversitesi Sosyal Bilimler Enstitüsü Dergisi, 8(15), 421-434.

Özkan, M. ve Arslantaş, H. İ. (2013). Etkili öğretmen özellikleri üzerine sıralama yöntemiyle bir ölçekleme çalışması. Trakya Üniversitesi Sosyal Bilimler Dergisi, 15(1), 311-330.

Özyürek, M. (2008). Nitelikli öğretmen yetiştirmede sorunlar ve çözümler: Özel eğitim örneği. Türk Ĕgitim Bilimleri Dergisi, 6(2), 189-226.

Page, D. (2013). Teacher misbehaviour: An analysis of disciplinary orders by the General Teaching Council for England. British Educational Research Journal, 39(3), 545-564.

Pajak, E. (2011). The "Bad" teacher: Some thoughts and questions for supervision. International Journal of Sciences Research, 1(2), 1-8.

Pala, A. (2005). Sınıfta istenmeyen öğrenci davranışlarını önlemeye dönük disiplin modelleri. Kirgızistan-Türkiye Manas Üniversitesi Sosyal Bilimler Dergisi, 13, 171-179.

Roberson, T. G., ve Doebler, L. K. (2001). Problems of secondary student teachers as perceived by cooperating teachers and high school students: A follow-up study. Education, 109(4), 497-503.

Rothman, R. (1990). Educators focus attention on ways to boost student motivation. Education Week, 11-13. 
Semlak, J. L., ve Pearson, J. C. (2008). Through the years: An examination of instructor age and misbehavior on perceived teacher credibility. Communication Research Reports, 25(1), 76-85.

Sezer, Ş. (2018). Öğretmenlerin sınıf yönetimi tutumlarının öğrencilerin gelişimi üzerindeki etkileri: Fenomenolojik bir çözümleme. Hacettepe Üniversitesi Ĕ̆itim Fakültesi Dergisi, 33(2), 534-549.

Strikwerda-Brown, J., Oliver, R., Hodgson, D., Palmer, M., ve Watts, L. (2008). Good teachers/bad teachers: How rural adolescent students' views of teachers impact on their school experiences. Australian Journal of Teacher Education, 33(6), 3.

Sünbül, A. M. (1996). Öğretmen niteliği ve öğretimdeki rolleri. Kuram ve Uygulamada Ĕ̆itim Yönetimi, 8(8), 597-608.

Şahin, A. (2011). Öğretmen algılarına göre etkili öğretmen davranışları. Journal of Kirsehir Education Faculty, 12(1), 240-259.

Şentürk, H. (2007). Uygulama liselerindeki rehber öğretmenlerin sinıf yönetimi yaklaşımları. Dü Ziya Gökalp Ĕ̆itim Fakültesi Dergisi, 8, 7-16.

Tor, H. ve Sargın, N. (2005). İlköğretim okullarının ikinci kademesinde okuyan öğrencilerin şiddet hakkındaki görüşleri. XIV. Ulusal Ĕ̆itim Bilimleri Kongresi, Tarih, Denizli, 28-30.

Weishew, N. L., ve Peng, S. S. (1993). Variables predicting students' problem behaviors. The Journal of Educational Research, 87(1), 5-17.

Yıldırım, A. ve Şimşek, H. (2008). Sosyal bilimlerde nitel araştırma yöntemleri. Ankara: Seçkin Yayıncılık.

Yıldırım, İ. ve Akan, D. (2018). İstenmeyen öğretmen davranışları ile öğrencilerin okula yönelik tutumları arasındaki ilişkinin incelenmesi. Inönü Üniversitesi Ĕ̆itim Fakültesi Dergisi, 19(3), 88-103.

\section{Kaynakça Bilgisi / Citation Information}

Katıtaş, S. (2019). Okul yöneticilerinin öğretmenlerin olumsuz davranışlarına yönelik görüşleri. OPUS-Uluslararası Toplum Araştırmaları Dergisi, 14(20), 441-468. DOI: 10.26466/opus.593581 